Article

\title{
Study on Temperature-Dependent Properties and Fire Resistance of Metakaolin-Based Geopolymer Foams
}

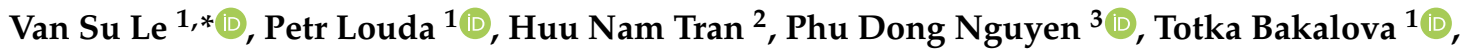 \\ Katarzyna Ewa Buczkowska ${ }^{1,4}$ (D) and Iva Dufkova ${ }^{1}$ \\ 1 Department of Material Science, Faculty of Mechanical Engineering, Technical University of Liberec, \\ Studentska 2, 46117 Liberec, Czech Republic; petr.louda@tul.cz (P.L.); totka.bakalova@tul.cz (T.B.); \\ katarzyna.ewa.buczkowska@tul.cz (K.E.B.); iva.dufkova@tul.cz (I.D.) \\ 2 Department of Applied Mechanics, Faculty of Mechanical Engineering, Technical University of Liberec, \\ Studentska 2, 46117 Liberec, Czech Republic; thnam.hut@gmail.com \\ 3 Department of Vehicles and Engines, Faculty of Mechanical Engineering, Technical University of Liberec, \\ Studentska 2, 46117 Liberec, Czech Republic; nguyenphudong89@gmail.com \\ 4 Department of Materials Technology and Production Systems, Faculty of Mechanical Engineering, \\ Lodz University of Technology, Stefanowskiego 1/15, 90-924 Lodz, Poland \\ * Correspondence: su.le.van@tul.cz or longsuvp90@gmail.com
}

Received: 16 November 2020; Accepted: 14 December 2020; Published: 15 December 2020

\begin{abstract}
This paper presents temperature-dependent properties and fire resistance of geopolymer foams made of ground basalt fibers, aluminum foaming agents, and potassium-activated metakaolin-based geopolymers. Temperature-dependent properties of basalt-reinforced geopolymer foams (BGFs) were investigated by a series of measurements, including apparent density, water absorption, mass loss, drying shrinkage, compressive and flexural strengths, XRD, and SEM. Results showed that the apparent density and drying shrinkage of the BGFs increase with increasing the treated temperature from 400 to $1200{ }^{\circ} \mathrm{C}$. Below $600{ }^{\circ} \mathrm{C}$ the mass loss is enhanced while the water absorption is reduced and they both vary slightly between 600 and $1000{ }^{\circ} \mathrm{C}$. Above $1000{ }^{\circ} \mathrm{C}$ the mass loss is decreased rapidly, whereas the water absorption is increased. The compressive and flexural strengths of the BGFs with high fiber content are improved significantly at temperatures over $600{ }^{\circ} \mathrm{C}$ and achieved the maximum at $1200{ }^{\circ} \mathrm{C}$. The BGF with high fiber loading at $1200^{\circ} \mathrm{C}$ exhibited a substantial increase in compressive strength by $108 \%$ and flexural strength by $116 \%$ compared to that at room temperature. The enhancement in the BGF strengths at high temperatures is attributed to the development of crystalline phases and structural densification. Therefore, the BGFs with high fiber loading have extraordinary mechanical stability at high temperatures. The fire resistance of wood and steel plates has been considerably improved after coating a BGF layer on their surface. The coated BGF remained its structural integrity without any considerable macroscopic damage after fire resistance test. The longest fire-resistant times for the wood and steel plates were 99 and $134 \mathrm{~min}$, respectively. In general, the BGFs with excellent fire resistance have great potential for fire protection applications.
\end{abstract}

Keywords: geopolymer foam; basalt fiber; high temperature; fire resistance

\section{Introduction}

The term "Geopolymer" was first introduced by Joseph Davidovits in the late 1970s [1]. Geopolymer material is an amorphous aluminosilicate binder material. Geopolymers have been shown as a green alternative to ordinary Portland cement (OPC) due to their excellent mechanical properties, low permeability, low $\mathrm{CO}_{2}$ emissions, good chemical resistance, and excellent fire resistance [2]. 
Because of these advantageous properties, geopolymers have been used for making foam concretes, fire-resistant coatings, fiber-reinforced composites, etc. [3]. Among the products based on geopolymers, geopolymer foams (GFs) with highly porous structures have been considered as the most attractive materials over the past few years, because they possess exceptional properties, lightweight, low cost, and good fire and chemical resistances [4-6]. GFs can be prepared by several approaches including direct foaming, replica method, sacrificial filler method, and additive manufacturing [4]. Among these synthesis approaches, the direct foaming method is the most used technique for producing GFs using chemical blowing agents, such as hydrogen peroxide [7-11], metal powders [12-15], or silica fumes [16-18]. GFs have been used not only as sustainable building materials but also in a variety of applications, such as thermal and acoustic insulators [19-21], adsorbents and filters [7,22-25], and fire resistance [26-29].

Effects of elevated temperatures on properties of geopolymer materials have been extensively studied [30-36]. Geopolymers indicated a decrease in the mechanical strength when exposed to elevated temperatures [30-33]. Chithambaram et al. [31] reported that the compressive strength of geopolymer mortar reduced and its mass loss increased with increasing sample heating temperature to $1000{ }^{\circ} \mathrm{C}$. Yang et al. [32] showed a reduction in the compressive strength and Young's modulus of geopolymer made of red mud slurry and class $\mathrm{F}$ fly ash with the temperature rise to $1000{ }^{\circ} \mathrm{C}$. Kürklü [33] indicated that coarse fly ash-based geopolymer mortars lost around $58 \%$ of strength at $1000{ }^{\circ} \mathrm{C}$. However, several studies on GFs have shown that GFs exposed to high temperatures have good strength maintenance and low thermal shrinkage [34-36]. František et al. [34] reported that the mechanical properties of fly ash-based GFs were improved and stable at $1000{ }^{\circ} \mathrm{C}$ over the investigated period of a year. Hlaváček et al. [35] showed that the compressive strength of alkali-activated fly ash GFs improved significantly when samples heated at $1100^{\circ} \mathrm{C}$. Cilla et al. [36] indicated that the increase of treated temperatures caused a substantial enhancement in the compressive strength due to sintering and formation of crystalline phases.

Porous geopolymer materials have been widely considered in the field of fire protection due to their low density, low thermal conductivity, and excellent thermal insulation performance [26-29]. Sakkas et al. [26] showed that potassium based geopolymers retained its structure entirely after the fire test without any significant macroscopic damage and exhibited excellent fire resistant properties. Sarker et al. [27] examined the fire endurance of steel-reinforced fly ash geopolymer and OPC concrete plates. The geopolymer concrete elements showed greater fire resistance than the OPC counterparts. Peng et al. [28] reported that the amorphous skeleton structures of alkali-activated GFs have been converted to smooth ceramics after the treatment at high temperatures. Therefore, these GFs have a stable porous structure and extraordinary fire resistance. Shuai et al. [29] studied the fire resistance of phosphoric acid-based GFs and reported that the GFs possess quite low thermal conductivity and are useful for fire resistance applications. In addition, acid-based geopolymer materials could maintain structural stability and excellent mechanical properties at high temperatures $[37,38]$. The exceptional stability at high temperatures makes geopolymers as robust candidates in the development of GFs for fire protection.

GFs have been produced by a combination of geopolymer paste and fillers such as quartz sand, fly ash, silica fume, and foaming agents. Besides, several chopped fibers, e.g., organic fiber, glass fiber, basalt fiber, and mineral fiber have been used as the reinforcements in GFs to improve their mechanical strengths. Currently, GFs are excellent alternatives to several materials such as polystyrene, mineral wool, and glass, because they are a non-flammable material characterized by relatively good insulation [39]. Study of the effect of high temperatures over $1000{ }^{\circ} \mathrm{C}$ on the properties of GFs is essential to determine their fire resistance applicability. In this paper, basalt fiber-reinforced geopolymer foams (BGFs) made of ground basalt fibers, aluminum foaming agent, and potassium-activated metakaolin-based geopolymer have been produced. Effects of high temperatures to $1200{ }^{\circ} \mathrm{C}$ on the physical and mechanical properties of the BGFs, namely apparent density, water absorption, mass loss, drying shrinkage, and compressive and flexural strength were investigated. The BGFs were exposed to 
desired elevated temperatures for $2 \mathrm{~h}$ before measurements. The fire resistance of wood strand boards and steel plates coated by a protective BGF layer was examined through the fire resistance tests. The fire resistance test presented in this paper is not so commonly known. Changes in the porous structure, crystal structure, and chemical composition of BGFs after heat treatment at high temperatures and after fire resistance testing were presented. We explored potential use of potassium-activated BGFs for fire protection applications.

\section{Materials and Methods}

\subsection{Materials}

The industrially commercial geopolymer "Baucis $1 k^{\prime}$ supplied by České Lupkové Závody, a.s. (Nové Strašecí, Czech Republic) is a two-component aluminosilicate binder based on metakaolin activated by alkaline solution of potassium. Basalt fibers were provided by Basaltex, a.s. (Šumperk, Czech Republic) and had a density of $2900 \mathrm{~kg} \cdot \mathrm{m}^{-3}$ and thermal conductivity of $0.027 \div 0.033 \mathrm{~W} / \mathrm{m} . \mathrm{K}$. The basalt fibers were ground using a grinding machine Bosch MW2514W (Robert Bosch GmbH, Stuttgart, Germany). The chemical compositions of the geopolymer Baucis $1 \mathrm{k}$ and basalt fiber determined by X-ray fluorescence (BRUKER S8 Tiger instrument, BRUKER, Karlsruhe, Germany) used in making the BGF samples were analyzed and presented in Table 1. Round-shaped aluminum powders D50 with the mean size of $51.47 \mu \mathrm{m}$ was supplied by Pkchemie Inc. (Třebíč, Czech Republic) were used to create pores inside the BGFs. The aluminum powder is $98 \%$ pure aluminum and has a chemical composition of $0.35 \% \mathrm{FeO}, 0.4 \% \mathrm{SiO}$, and $0.02 \% \mathrm{Cu}$ by weight. Photographs showing the materials for processing the BGFs are described in Figure 1.

Table 1. Chemical compositions of geopolymer Baucis lk and basalt fiber (wt.\%).

\begin{tabular}{ccccccccccccc}
\hline Constituents & $\mathrm{SiO}_{2}$ & $\mathrm{Al}_{2} \mathrm{O}_{3}$ & $\mathrm{CaO}$ & $\mathbf{M g O}$ & $\mathrm{TiO}_{2}$ & $\mathrm{Fe}_{2} \mathbf{O}_{3}$ & $\mathbf{K}_{2} \mathbf{O}$ & $\mathrm{SO}_{3}$ & $\mathbf{M n O}$ & $\mathbf{N a}_{2} \mathbf{O}_{2}$ & $\mathbf{P}_{2} \mathbf{O}_{5}$ & LOI \\
\hline Geopolymer & 44.5 & 28.9 & 17.6 & 2.23 & 1.31 & 0.82 & 0.75 & 0.46 & 0.28 & 0.25 & - & 2.56 \\
\hline Basalt fiber & 33.6 & 14.4 & 26.1 & 8.26 & 1.98 & 6.61 & 1.21 & 0.29 & 0.76 & 1.38 & 0.14 & 2.05 \\
\hline
\end{tabular}
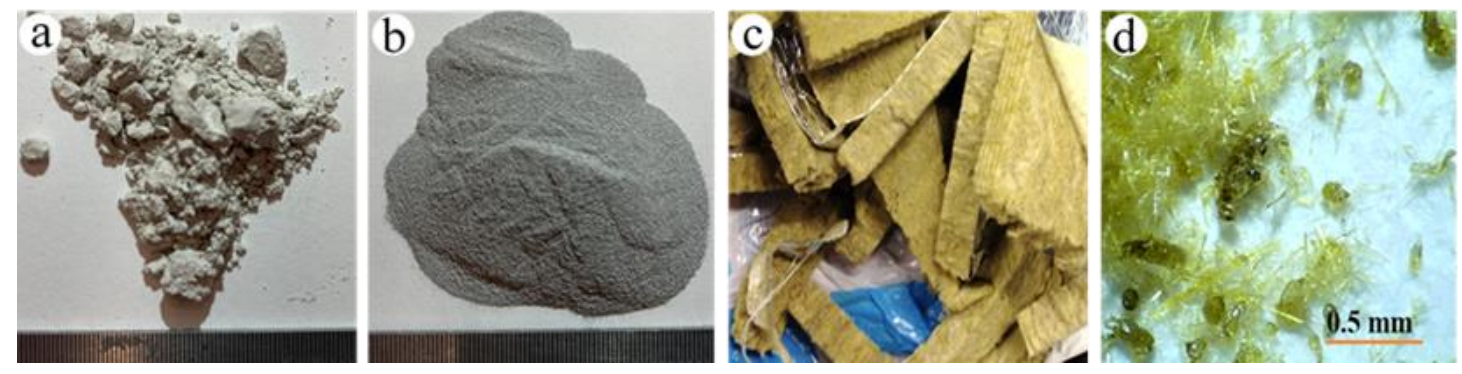

Figure 1. Photographs showing the materials: (a) geopolymer Baucis lk, (b) aluminum powders, (c) basalt fibers before grinding, and (d) basalt fibers after grinding.

\subsection{Fabrication of BGFs}

The BGFs were prepared by three following steps: (1) to begin with, a geopolymer mortar was prepared by mixing metakaolin-based geopolymer Baucis $1 \mathrm{k}$ with an alkaline solution of potassium in a predetermined ratio (liquid to solid) by mechanical stirring; (2) afterwards, the ground basalt fibers were added to the geopolymer mortar mixture and the mixture was homogenized by the mechanical stirring; and (3) finally, aluminum powders were added to the mixture to create the BGF. Foaming of the mixture was carried out by the mechanical stirring. Three BGF samples with different mixing ratios and basalt fiber contents presented in Table 2 were prepared. All BGF samples for the measurement of mechanical and physical properties were cast in the mold and were cured for 28 days at room 
temperature (RT). The thermal conductivities of the samples S1, S2, and S3 were measured, respectively, as $0.137,0.143$, and $0.131 \mathrm{~W} / \mathrm{m} \cdot \mathrm{K}[6]$.

Table 2. Mix proportions of basalt fiber-reinforced geopolymer foam (BGF) samples by weight ratio.

\begin{tabular}{ccccc}
\hline \multirow{2}{*}{ BGF Sample } & \multicolumn{2}{c}{ Binder } & \multirow{2}{*}{ Aluminum Powder/Binder } & Basalt Fiber/Binder \\
\cline { 2 - 3 } & Baucis lk & Activator & & 0.05 \\
S1 & \multirow{2}{*}{1} & 0.9 & 0.008 & 0.16 \\
S2 & & & 0.008 & 0.26 \\
S3 & & & & 0.08 \\
\hline
\end{tabular}

\subsection{Heat Treatment of the BGFs}

To assess the properties of the BGFs at elevated temperatures, samples were exposed to elevated temperatures at $200,400,600,800,1000$, and $1200{ }^{\circ} \mathrm{C}$. The BGF specimens were heated in a furnace at a heating rate of $5{ }^{\circ} \mathrm{C} / \mathrm{min}$ until the desired temperatures and were kept at each temperature in the furnace for $2 \mathrm{~h}$. The heated BGF samples were then naturally cooled down to RT in the furnace. The heat treatment process of the BGF samples is presented in Figure 2.

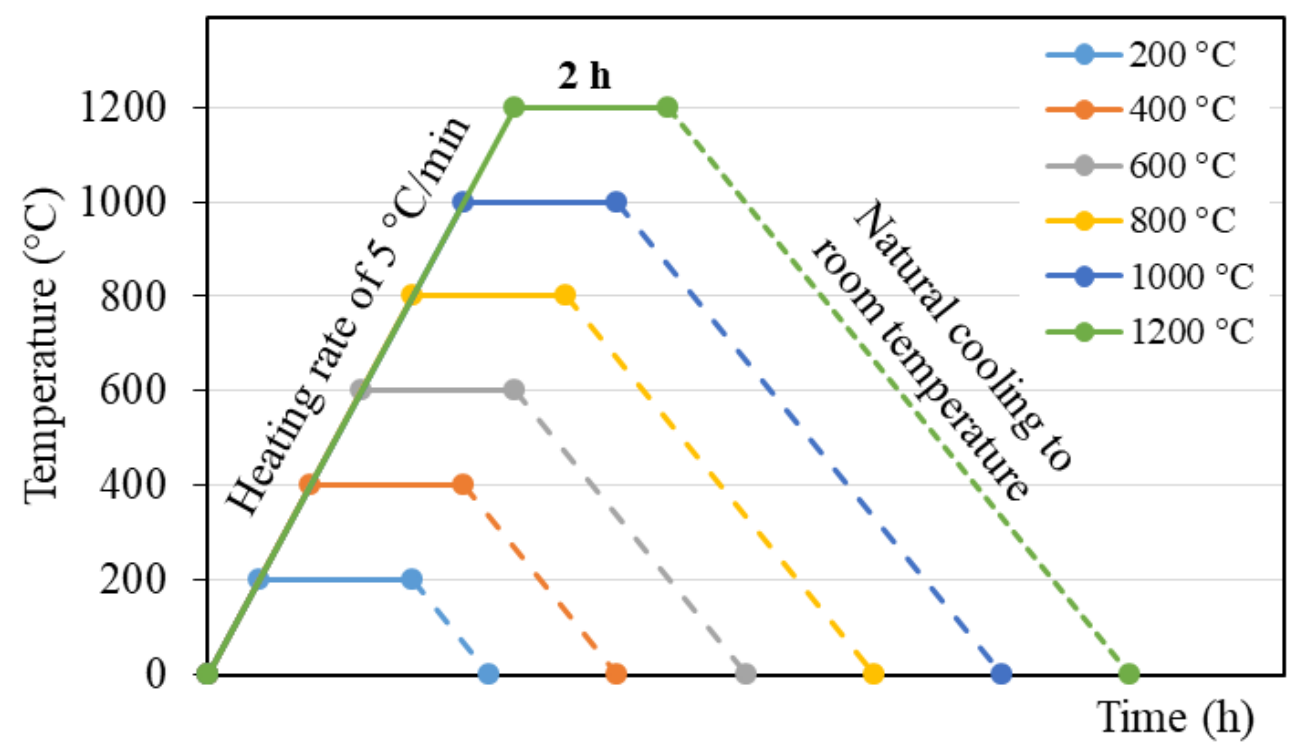

Figure 2. Heat treatment process of the BGF samples.

\subsection{Characterizations}

The apparent density, water absorption, mass loss, and drying shrinkage of the unexposed and exposed BGFs to elevated temperatures were investigated. The BGF samples with the dimensions of 40 by 40 by $160 \mathrm{~mm}^{3}$ were used to measure the physical properties. Three specimens from each sample group were tested and their mean values were calculated for the physical properties of BGFs. The apparent density of BGFs was measured according to standard ČSN EN 1936 and was estimated by dividing the mass of the sample by its apparent volume.

Water absorption is used to measure the permeability of the BGFs. Water absorption of the BGFs was determined by the mass change between the dry and wet specimens using the standard ASTM C642-06. The dry samples were cured in an oven at the temperature of $100-110{ }^{\circ} \mathrm{C}$ for at least $24 \mathrm{~h}$. The wet samples were soaked in the water for a $24 \mathrm{~h}$ interval. The water absorption was calculated using the following equation:

$$
W a \%=\frac{A-A_{0}}{A_{0}} \times 100 \%
$$


where $W a$ is the percentage of water absorption, $A_{0}$ is the mass of the dry sample (g), and $A$ is the mass of the wet sample $(\mathrm{g})$.

The drying shrinkage of the BGFs was determined by measuring the length of the BGF samples before and after exposure to elevated temperatures. The difference in length of samples before and after exposure to elevated temperatures indicates the drying shrinkage. Similar method was also used to determine the mass loss of BGFs after exposure to elevated temperatures.

A scanning electron microscope (SEM) ZEISS Ultra Plus equipped with EDX detector (ZEISS, Oberkochen, Germany) was used to investigate microstructural morphology of the unexposed and exposed BGFs to elevated temperatures. X-ray diffraction (XRD) analysis was performed to examine the phase composition and the crystalline content of metakaolin-based geopolymer and basalt fibers at different temperatures. XRD patterns were recorded using a Bruker D8 Advance XRD system equipped with a Bruker SSD 160 detector and operating with $\mathrm{Cu}-\mathrm{K} \alpha$ radiation at $40 \mathrm{kV}$ and $25 \mathrm{~mA}$.

\subsection{Mechanical Testing}

Mechanical testing was conducted to measure mechanical strengths of the unexposed and exposed BGFs to elevated temperatures. Compressive strength of the BGFs was measured using $40 \mathrm{~mm}^{3}$ cubic specimens. Flexural strength was measured from a three-point bending test for the samples with a span length of $100 \mathrm{~mm}$ and the dimensions of 40 by 40 by $160 \mathrm{~mm}^{3}$. The compressive and bending tests were conducted with a load cell of $10 \mathrm{kN}$ at a crosshead speed of $2.0 \mathrm{~mm} / \mathrm{min}$ at laboratory temperature of about $22 \pm 3{ }^{\circ} \mathrm{C}$ using a universal testing machine Instron (Model 4202). Mean values of compressive and flexural strengths were obtained from three specimens for each series.

\subsection{Fire Resistance Test}

To evaluate the fire protection of the BGFs, the fire resistance tests were conducted on the wood strand boards and steel plates coated with a BGF layer type S3. Fire resistance specimens were fabricated by coating the BGF mixture type $\mathrm{S} 3$ on the surface of wood and steel plates by casting and were cured for 28 days at RT before testing. The thicknesses of wood and steel boards before coating the BGF layer are 22 and $2 \mathrm{~mm}$, respectively. The fire resistance samples have a 2D dimension of 500 by $500 \mathrm{~mm}^{2}$. The fire exposure region of the samples was $300 \mathrm{by} 300 \mathrm{~mm}^{2}$. The thicknesses of the coated BGF layers for the fire resistance specimens are presented in Table 3.

Table 3. Wood and steel samples for fire resistance test.

\begin{tabular}{cccccccc}
\hline Base Material & \multicolumn{3}{c}{ Wood } & \multicolumn{3}{c}{ Steel } \\
\hline Sample ID & WS1 & WS2 & WS3 & SS1 & SS2 & SS3 \\
\hline Thickness of the coated BGF layer $(\mathrm{mm})$ & 0 & 10 & 20 & 0 & 5 & 10 \\
\hline
\end{tabular}

The inside, outside and chimney temperatures of the fire test furnace were measured using in-built thermocouples connected to the computer by ADAM 4000 series. The respective thermocouples T1, T2, and T3 were mounted on the fire-exposed surface of the specimen, unexposed sample surface, and in the furnace chimney. The fire test furnace, position of thermocouples, the ADAM 4000 series system, laptop, and others were depicted in Figure 3. 


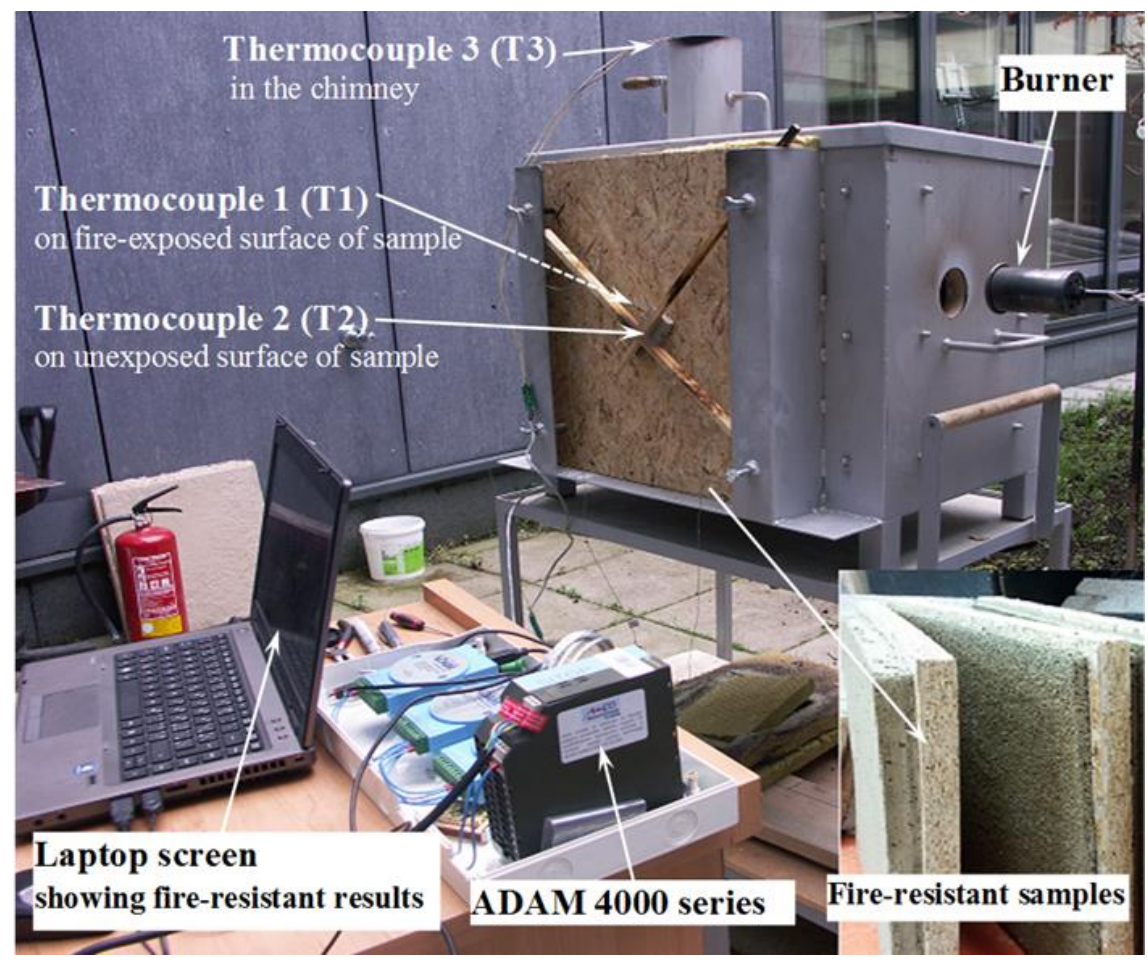

Figure 3. An image illustrating equipment for fire resistance test.

The test furnace was heated by a system of natural gas. The fire resistance test for the wood specimens was stopped once shiny spots began to appear on the non-fire surface of samples and a little smoke escaped. The endpoint of the fire resistance test for the steel specimens was done when observing the deformation (e.g., buckling and warping defects) of the unexposed surface or the measured temperature on the unexposed surface of samples reached $300{ }^{\circ} \mathrm{C}$ using an infrared thermometer Voltcraft IR 650-16D. The furnace fire was controlled to obtain the heating rate recommended in the standard ISO 834 [40]. The furnace temperature was determined by the following equation:

$$
T_{t}=T_{0}+345 \log _{10}(8 t+1)
$$

where $T_{\mathrm{t}}$ is the furnace temperature $\left({ }^{\circ} \mathrm{C}\right)$ at time $t(\mathrm{~min})$ and $T_{0}$ is the initial temperature $\left({ }^{\circ} \mathrm{C}\right)$.

\section{Results and Discussion}

\subsection{Temperature-Dependent Properties}

The physical and mechanical properties of the unexposed and exposed BGFs to elevated temperatures were measured. The apparent density, water absorption, mass loss, and drying shrinkage as functions of temperature for the BGFs are shown in Figure 4. Effects of high temperatures on the compressive and flexural strengths of the BGFs are presented in Figure 5. Photographs describing the structural morphologies of unexposed and exposed BGFs to elevated temperatures are given in Figure 6. Optical photographs illustrating the microstructural morphologies of untreated and heat-treated BGF specimens are presented in Figure 7. SEM micrographs of unexposed and fire-exposed BGF samples type 33 at a number of specific temperatures are portrayed in Figure 8. XRD patterns of the metakaolin-based geopolymer and basalt fiber after heat treatment at different elevated temperatures are shown in Figure 9. The chemical element compositions of the unexposed and exposed BGF sample S3 to elevated temperatures which were determined using SEM equipped with EDX detector are given in Table 4. 

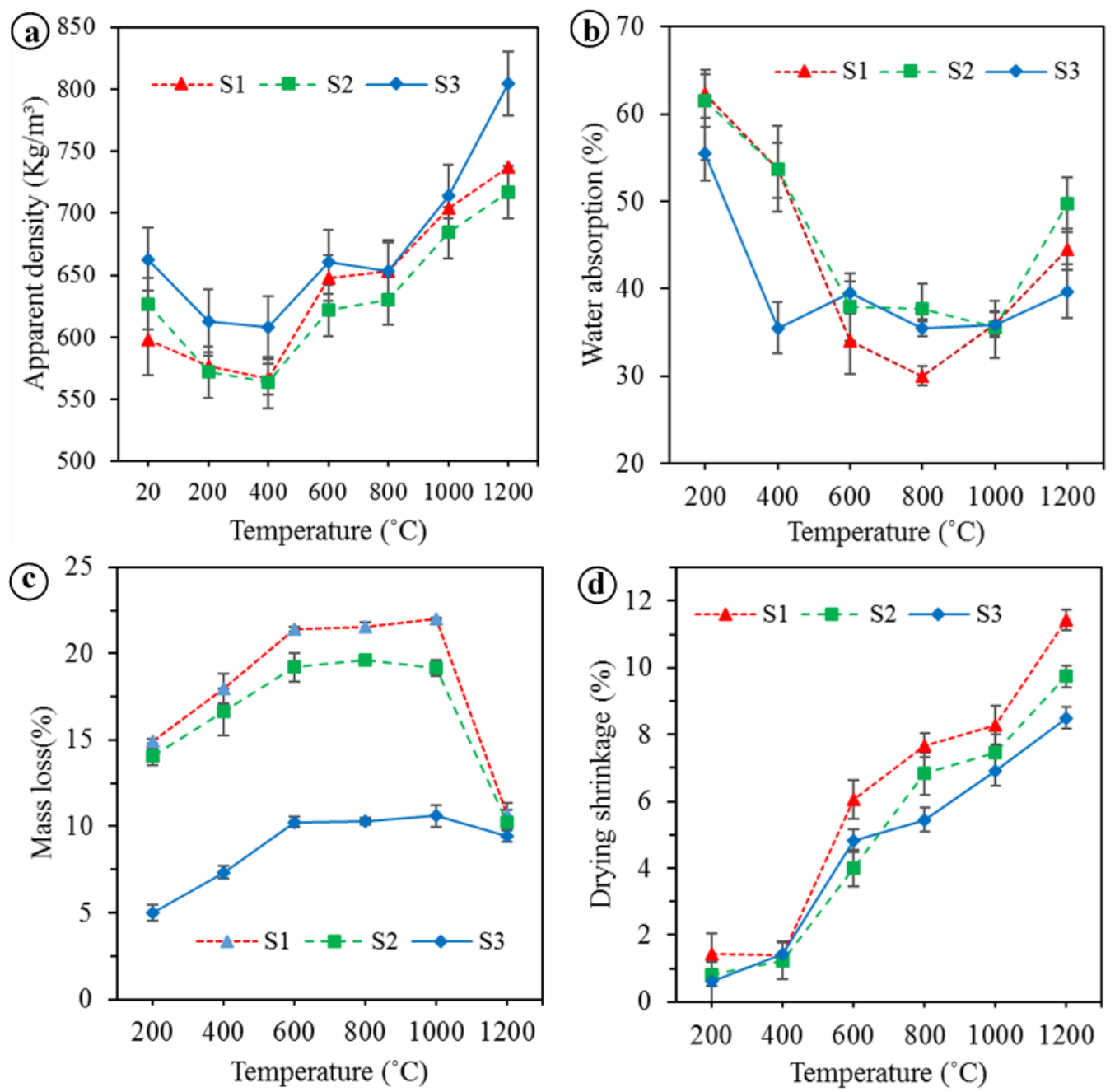

Figure 4. The physical properties of the BGFs at different temperatures: (a) apparent density, (b) water absorption, (c) mass loss, and (d) drying shrinkage.
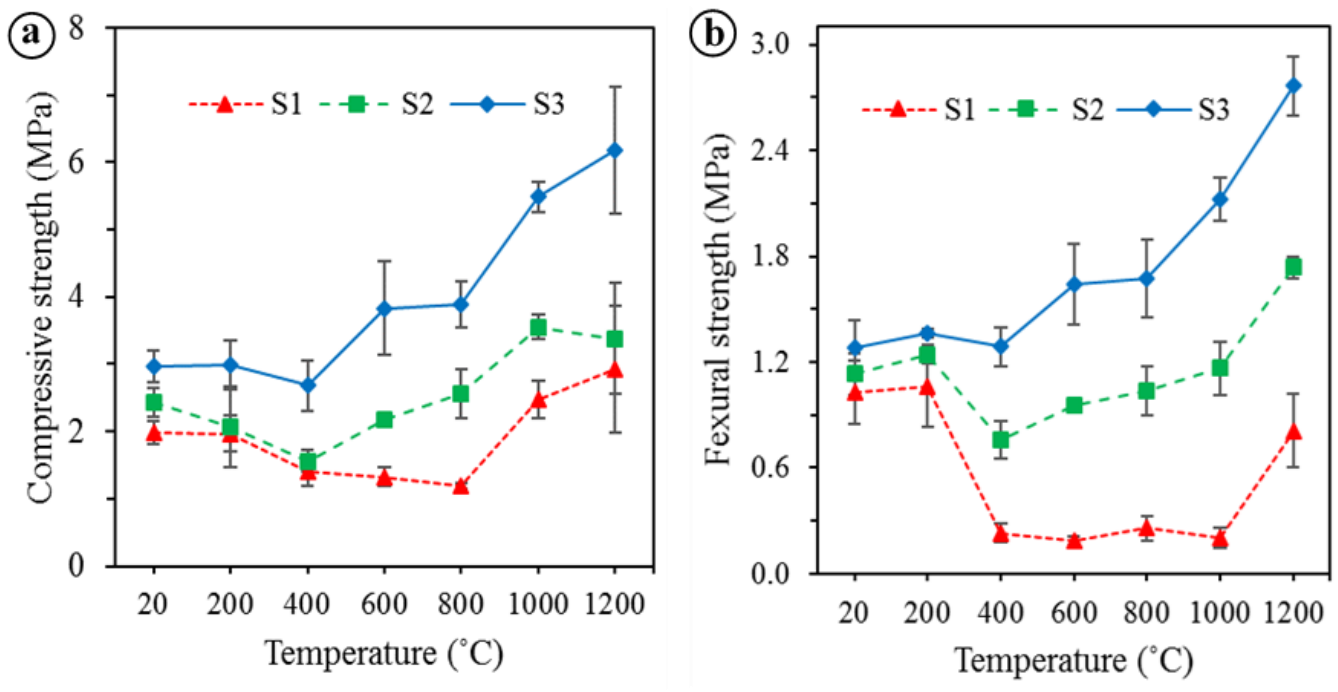

Figure 5. (a) Compressive strength and (b) flexural strength of the BGFs at different temperatures. 
As observed in Figure 4a, the apparent density of the BGFs decreases slightly with increasing the treated temperature to $400{ }^{\circ} \mathrm{C}$, then enhances as the temperature increases to $600{ }^{\circ} \mathrm{C}$. The apparent density does not vary significantly at temperatures between 600 and $800{ }^{\circ} \mathrm{C}$, but increases rapidly with the rise of the temperature from 800 to $1200^{\circ} \mathrm{C}$. The respective densities of the S1, S2, and S3 after heat treatment at $1200{ }^{\circ} \mathrm{C}$ were $737,717.1$, and $804.8 \mathrm{~kg} / \mathrm{m}^{3}$ and they increased by $23.2 \%, 14.4 \%$, and $21.4 \%$ compared to those at RT. Figure $4 \mathrm{~d}$ showed that the drying shrinkage of the BGFs changes slightly with the rise of treated temperatures until $400{ }^{\circ} \mathrm{C}$, then enhances sharply over $400{ }^{\circ} \mathrm{C}$. The drying shrinkages of the S1, S2, and S3 at a temperature of 200 and $400{ }^{\circ} \mathrm{C}$ were only approximately $1 \%$, but they respectively increased to $11.4 \%, 9.8 \%$, and $8.5 \%$ at $1200{ }^{\circ} \mathrm{C}$. Besides, when increasing the basalt fiber content, the drying shrinkage of the BGFs decreases. Moreover, the drying shrinkages of unexposed and exposed samples to elevated temperatures can be seen in Figure 6.
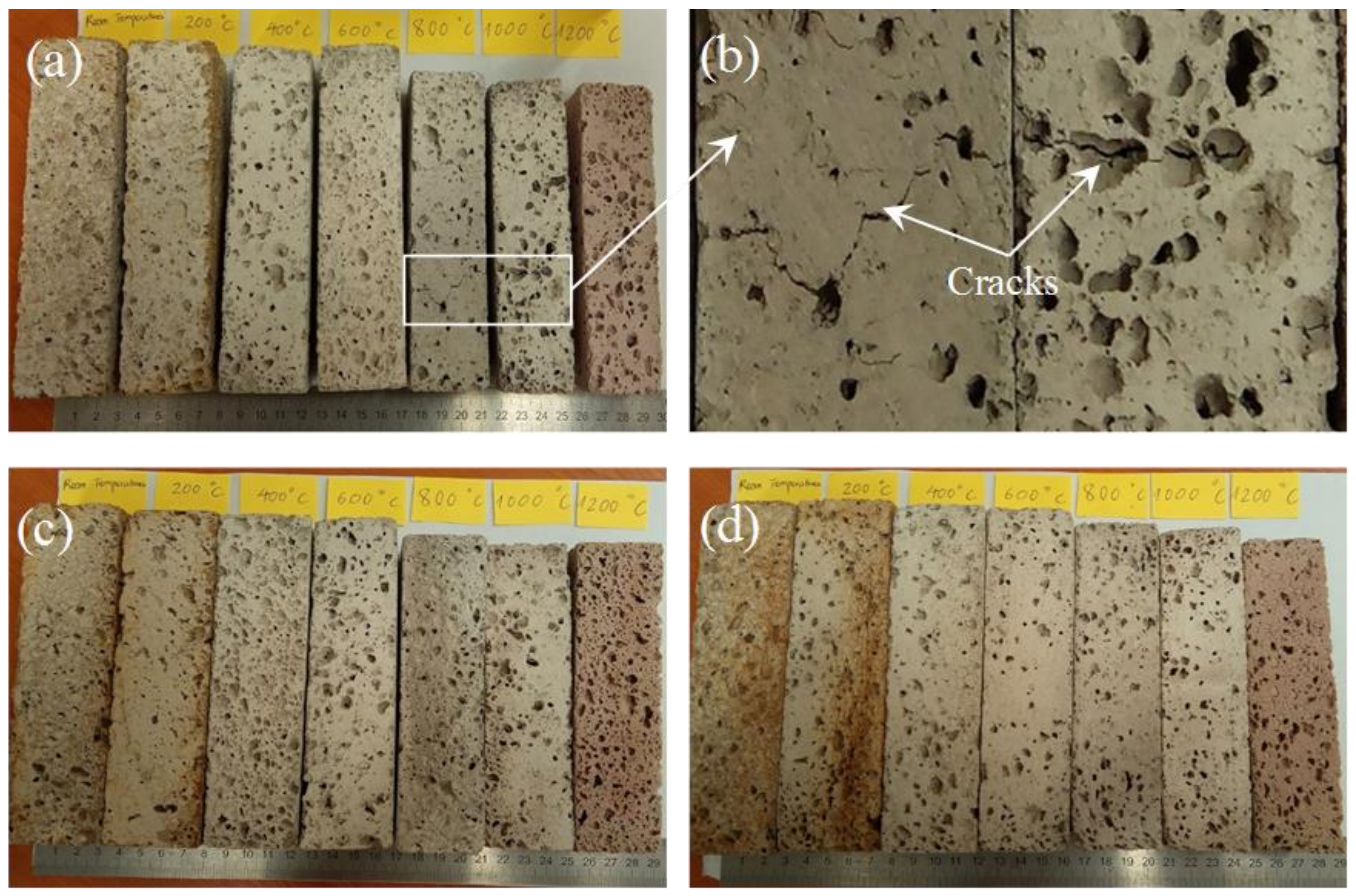

Figure 6. Photographs illustrating structural morphologies of different BGF samples after heat treatment at elevated temperatures: (a) and (b) S1, (c) S2, and (d) S3.

The water absorptions of the BGFs are presented in Figure $4 \mathrm{~b}$. As Figure $4 \mathrm{~b}$ shows, the highest water absorptions of the S1, S2, and S3 occurred at $200{ }^{\circ} \mathrm{C}$ were $62.3 \%, 61.5 \%$, and $55.4 \%$, respectively. The water absorption of the $\mathrm{S} 1$ decreases drastically with increasing the temperature from 200 to $800{ }^{\circ} \mathrm{C}$, then gradually increased as the temperature rises to $1200^{\circ} \mathrm{C}$. Similarly, the water absorption of the S2 dropped rapidly with the increase of the temperature from 200 to $600^{\circ} \mathrm{C}$, next changed moderately to $1000{ }^{\circ} \mathrm{C}$, and finally increased sharply to about $50 \%$ at $1200^{\circ} \mathrm{C}$. The water absorption of the sample S3 fell remarkably as the temperature rose to $400{ }^{\circ} \mathrm{C}$ and then fluctuates at around $35 \%$ beyond $400{ }^{\circ} \mathrm{C}$. It is interesting that the $\mathrm{S} 1, \mathrm{~S} 2$, and S3 showed the similar water absorption at a temperature of $1000^{\circ} \mathrm{C}$. Particularly, the water absorption of the sample S3 with higher basalt fiber content was lower than that of samples $\mathrm{S} 1$ and $\mathrm{S} 2$ at temperatures of below $600{ }^{\circ} \mathrm{C}$ and above $1000^{\circ} \mathrm{C}$.

The mass losses of the BGFs are shown in Figure 4c. The mass losses of the S1, S2, and S3 occurred at $200{ }^{\circ} \mathrm{C}$, respectively, were $14.9 \%, 14.0 \%$, and $5.0 \%$. Below $600{ }^{\circ} \mathrm{C}$ the mass loss of S3 was just about one third compared to that of the S1 and S2. The mass loss of the S1 and S2 raised with increasing the temperature to $600{ }^{\circ} \mathrm{C}$, then remained almost unchanged at temperatures between 600 and $1000^{\circ} \mathrm{C}$, and finally declined rapidly to about $10 \%$ at $1200{ }^{\circ} \mathrm{C}$. The mass loss of BGFs heated at $1200{ }^{\circ} \mathrm{C}$ was lower than that heated at $1000^{\circ} \mathrm{C}$, because the BGF samples exposed to $1200^{\circ} \mathrm{C}$ absorb more water 
during cooling than those exposed to $1000^{\circ} \mathrm{C}$. For the sample S3 with higher basalt fiber content, the variation of the mass loss below $1000{ }^{\circ} \mathrm{C}$ was the same as that of the S1 and S2. The mass loss of the S3 is almost constant at temperatures between 600 and $1000{ }^{\circ} \mathrm{C}$, then reduced slightly to about $10 \%$ at a temperature of $1200{ }^{\circ} \mathrm{C}$. Maximum mass losses for the S1, S2, and S3 exposed to $1000{ }^{\circ} \mathrm{C}$ were found to be $22 \%, 19.2 \%$, and $10.6 \%$, respectively. At $1200{ }^{\circ} \mathrm{C}$ the mass losses of the S1, S2, and S3 were approximately the same. It is interesting that the mass loss of the S3 was much lower than that of samples S1 and S2 at temperatures under $1000^{\circ} \mathrm{C}$. In general, below $1000^{\circ} \mathrm{C}$ the mass loss decreases drastically as the basalt fiber content in the BGFs increases.

S1
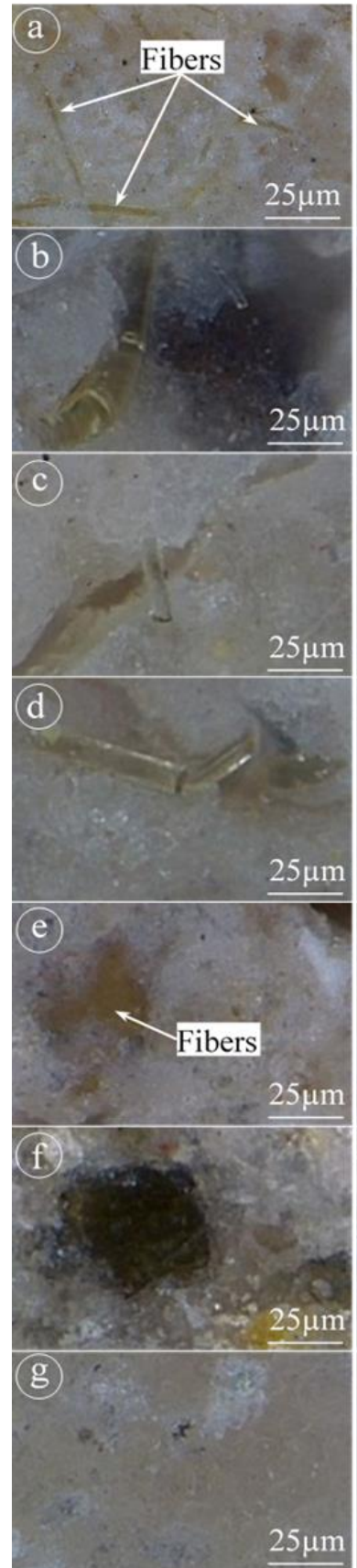

S2
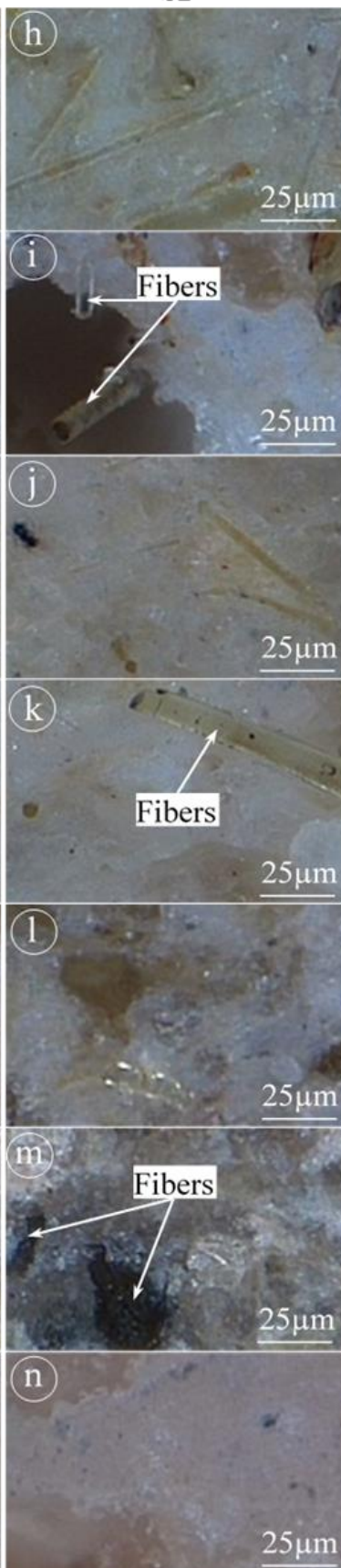

S3

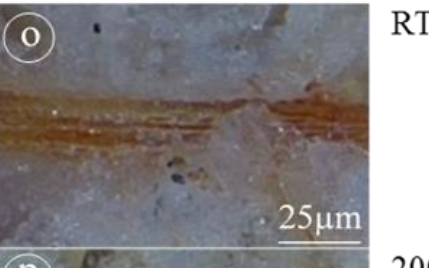

$200{ }^{\circ} \mathrm{C}$
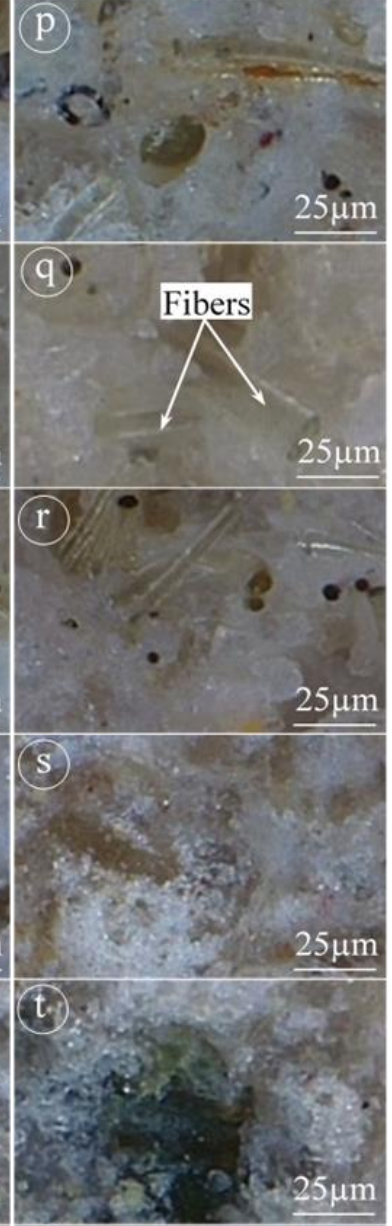

(1)

$1200^{\circ} \mathrm{C}$

Figure 7. Optical micrographs of BGF samples at elevated temperatures: (a-g) for S1, (h-n) for S2, and $(\mathbf{o}-\mathbf{u})$ for S3. 

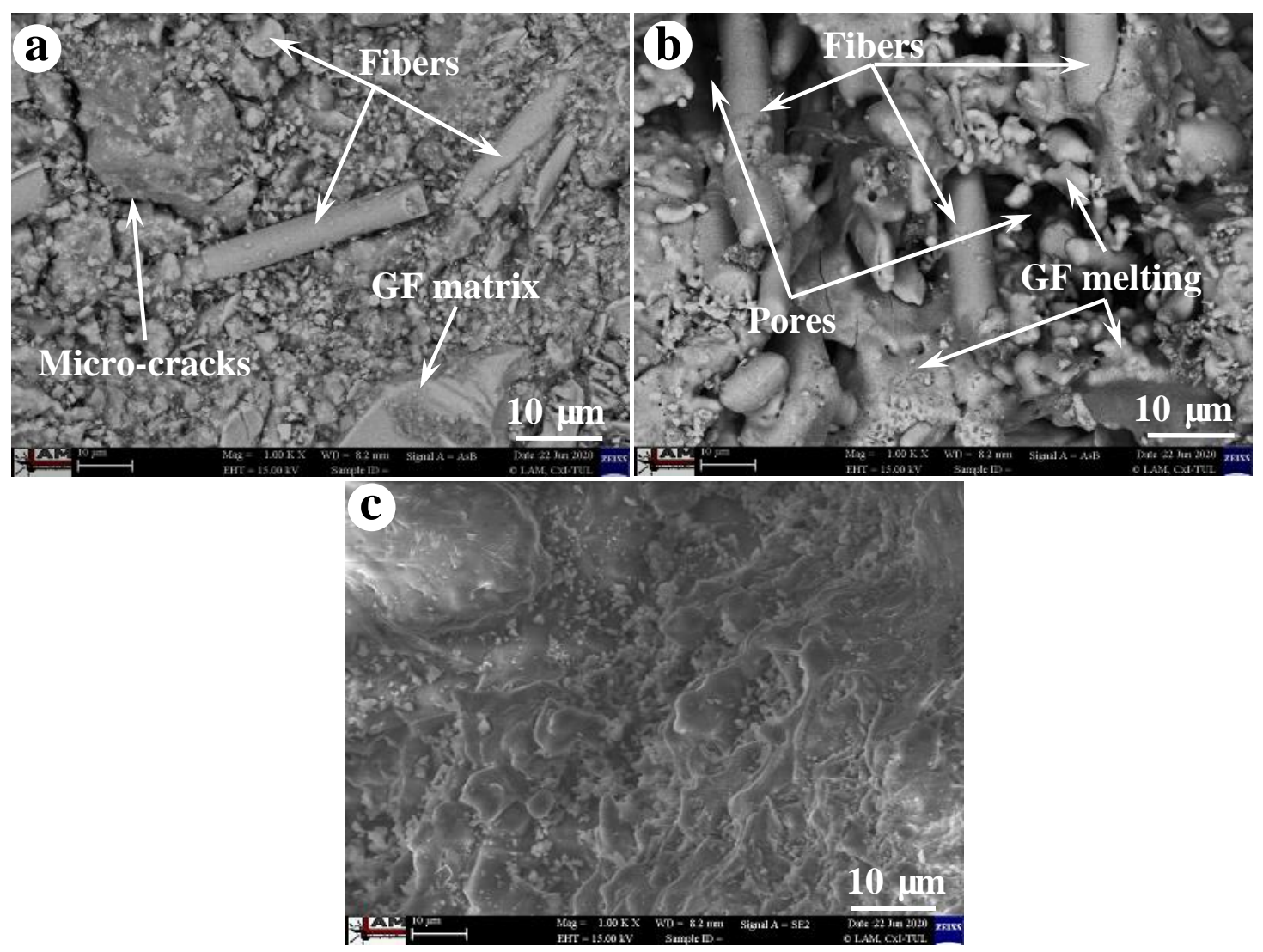

Figure 8. SEM micrographs of BGF samples type S3 at several specific temperatures: (a) room temperature (RT), (b) 1000 , and (c) $1200{ }^{\circ} \mathrm{C}$.

The compressive and flexural strengths of the BGFs are presented in Figure 5. As observed in Figure $5 \mathrm{a}$, the compressive strength of the BGFs changed somewhat at temperatures below $200{ }^{\circ} \mathrm{C}$ and then decreased slightly in the temperature range from 200 to $400{ }^{\circ} \mathrm{C}$. Once the temperature increased from 400 to $800^{\circ} \mathrm{C}$, the $\mathrm{S} 1$ showed a slight reduction in the compressive strength, while the S2 indicated an enhancement in the compressive strength. Unlike the S1 and S2, the S3 showed that the compressive strength increased with increasing the temperature to $600{ }^{\circ} \mathrm{C}$ and then remained constant between 600 and $800^{\circ} \mathrm{C}$. The compressive strengths of the S1, S2, and S3 enhance with the rise of the temperature from 800 to $1000^{\circ} \mathrm{C}$. As the temperature increased from 1000 to $1200^{\circ} \mathrm{C}$, the $\mathrm{S} 1$ and S3 showed an increase in the compressive strength, whereas the $\mathrm{S} 2$ indicates an inconsiderable reduction. Interestingly, the compressive strength of the BGFs heat-treated at $1200^{\circ} \mathrm{C}$ was improved significantly compared with that at temperatures below $200^{\circ} \mathrm{C}$. The respective samples S1, S2, and S3 after heating at $1200{ }^{\circ} \mathrm{C}$ showed an increase in the mean compressive strength by $48.0 \%, 39.1 \%$, and $107.6 \%$ compared to those at RT. In addition, the compressive strength enhanced with raising the basalt fiber content.

xSimilarly to the compressive strength, the flexural strength of the BGFs varied slightly at temperatures under $200{ }^{\circ} \mathrm{C}$ and then decreased at temperatures between 200 to $400{ }^{\circ} \mathrm{C}$ (see Figure $5 \mathrm{~b}$ ). A sharp reduction in the flexural strength occured for samples with low basalt fiber contents (S1 and S2). When the temperature rose from 400 to $800^{\circ} \mathrm{C}$, the variation in the flexural strength of the S1, S2, and S3 is similar to that of their compressive strength. Although the S2 and S3 showed an increase in the flexural strength at temperatures between 800 to $1000{ }^{\circ} \mathrm{C}$, the $\mathrm{S} 1$ indicated the unchanged flexural strength. All three samples showed a rapid increase in the flexural strength as the temperature enhanced from 1000 to $1200^{\circ} \mathrm{C}$. However, the sample S1 at $1200^{\circ} \mathrm{C}$ showed a lower flexural strength compared with that at RT, whereas the respective samples of S2 and S3 at $1200^{\circ} \mathrm{C}$ indicated a higher flexural strength by $53.6 \%$ and $115.9 \%$ compared to those at RT. It is clear from Figure $5 \mathrm{~b}$ that the 
flexural strength enhanced with the rise of basalt fiber content. Moreover, the flexural strengths of the BGF with highest fiber content (S3) was improved incredibly at high temperatures.
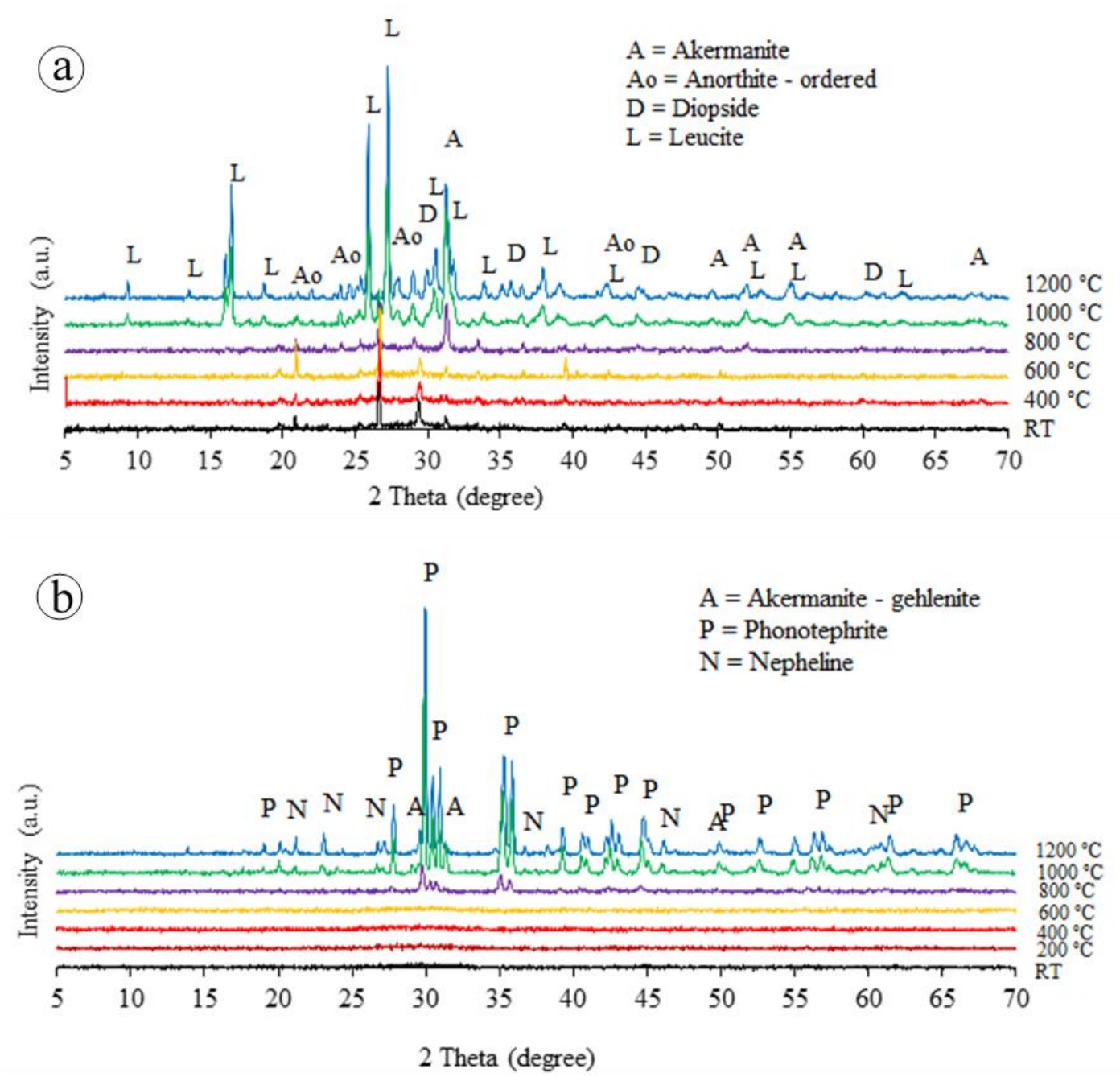

Figure 9. XRD patterns of (a) metakaolin-based geopolymer and (b) basalt fiber at different elevated temperatures.

Table 4. Chemical element composition of the sample S3 at different temperatures (wt.\%).

\begin{tabular}{cccccccccccccccc}
\hline Constituents & $\mathbf{C}$ & $\mathbf{O}$ & $\mathbf{N a}$ & $\mathbf{M g}$ & $\mathbf{A l}$ & $\mathbf{S i}$ & $\mathbf{P}$ & $\mathbf{S}$ & $\mathbf{C l}$ & $\mathbf{K}$ & $\mathbf{C a}$ & $\mathbf{T i}$ & $\mathbf{M n}$ & $\mathbf{F e}$ & Total \\
\hline $\mathrm{RT}$ & 5.59 & 45.76 & 0.20 & 1.05 & 10.23 & 17.91 & 0.00 & 0.06 & 0.11 & 10.0 & 7.91 & 0.42 & 0.21 & 0.56 & 100 \\
\hline $1000^{\circ} \mathrm{C}$ & 4.07 & 43.53 & 0.29 & 2.46 & 9.60 & 18.60 & 0.07 & 0.12 & 0.00 & 6.72 & 11.65 & 0.66 & 0.50 & 1.72 & 100 \\
\hline $1200^{\circ} \mathrm{C}$ & 4.77 & 43.96 & 0.29 & 1.55 & 10.52 & 21.48 & 0.03 & 0.05 & 0.00 & 7.82 & 8.24 & 0.40 & 0.19 & 0.71 & 100 \\
\hline
\end{tabular}

It is interesting that the compressive and flexural strengths of the BGF with highest fiber content (S3) were improved considerably at high temperatures over $600^{\circ} \mathrm{C}$. Unlike the S3, the S1 with low fiber loading showed a decrease in its compressive and flexural strengths at temperatures below $1000^{\circ} \mathrm{C}$. This reduction is attributable to macroscopic cracks appeared in samples (Figure 6b). However, the cracks did not appear in the BGF samples with the high fiber content (Figure $6 c, d)$. The strength increase of the S3 was due to reinforcing the basalt fibers in the metakaolin-based geopolymer, because basalt fibers showed a good strength and stiffness at high temperatures [41]. In addition, all three samples indicate a great enhancement in the compressive and flexural strengths as the temperature rose from 1000 to $1200{ }^{\circ} \mathrm{C}$. The improvement in the mechanical strengths of the BGFs at 
high temperatures is ascribable to their structural changes, including sintering, densification, melting, and porosity [4].

The occurrence of sintering, densification and melting makes decolorization in geopolymer mortars when the temperature over $1000{ }^{\circ} \mathrm{C}$ [32]. Figure 7 showed the decolorization and fiber appearance of the BGF samples when heating them at high temperatures. As observed in Figure 7 , the BGF samples have a similar color at temperatures below $200^{\circ} \mathrm{C}$. The color of the BGF samples changed slightly in the temperature range from 400 to $1000^{\circ} \mathrm{C}$. The BGF sample at $1200{ }^{\circ} \mathrm{C}$ looked brighter than the others at lower temperatures. In addition, basalt fibers are visible at temperatures below $1000{ }^{\circ} \mathrm{C}$ and were not observed at $1200{ }^{\circ} \mathrm{C}$. Ye et al. [32] reported that the increase in the compressive and flexural strengths of geopolymer mortars is attributable to melting and densification effects after heating at $1000{ }^{\circ} \mathrm{C}$. In our study, the melting of potassium-based geopolymer matrix was observed after the BGFs exposed to high temperatures over $1000{ }^{\circ} \mathrm{C}$ (Figure $8 \mathrm{~b}$ ). The melting of the geopolymer matrix caused the densification of the BGFs (Figures $7 \mathrm{u}$ and $8 \mathrm{c}$ ) and facilitated a strength increase at $1200{ }^{\circ} \mathrm{C}$ (Figure 5).

Moreover, the formation of ceramic phases in the BGFs at $1200^{\circ} \mathrm{C}$ (Figure 8) enhanced, considerably, their compressive and flexural strengths (Figure 5). The phase changes of the metakaolin-based geopolymer and basalt fibers at high temperatures are depicted in Figure 9. Evidently, there was the presence of amorphous phases in the metakaolin-based geopolymer at RT [28,36,42]. The XRD patterns in Figure 9a exhibited no significant phase change in the geopolymer samples below $800^{\circ} \mathrm{C}$. However, over $1000^{\circ} \mathrm{C}$ exposure the amorphous phases converted into crystalline phases due to geopolymerization mechanism, such as leucite $\left(\mathrm{KAlSi}_{2} \mathrm{O}_{6}\right)$, akermanite $\left(\mathrm{Ca}_{2} \mathrm{MgSi}_{2} \mathrm{O}_{7}\right)$, anorthite $\left(\mathrm{CaAl}_{2} \mathrm{Si}_{2} \mathrm{O}_{8}\right)$, and diopside $\left(\mathrm{CaMgSi}_{2} \mathrm{O}_{6}\right)$. These phases are stable crystalline phases and have a great stability at high temperatures. The strong peaks at $2 \theta$ angles of $27^{\circ}$ and $30^{\circ}$ in the geopolymer mainly identify the presence of leucite and akermanite phases at 1000 and $1200^{\circ} \mathrm{C}$. The leucite peaks at $1200^{\circ} \mathrm{C}$ are higher than those at $1000^{\circ} \mathrm{C}$.

The XRD patterns in Figure $9 \mathrm{~b}$ also showed that no remarkable phase change has taken on the basalt fiber exposed to $600{ }^{\circ} \mathrm{C}$, similarly to the metakaolin-based geopolymer (Figure 9a). Nevertheless, crystalline phases as akermanite, phonotephrite, and nepheline start to form at $800{ }^{\circ} \mathrm{C}$ and become stable around $1000^{\circ} \mathrm{C}$. The phonotephrite phase appeared in the basalt fiber peaks at $2 \theta$ angles of $30^{\circ}$ and $35^{\circ}$. Bayrak and Yilmaz reported that the akermanite and nepheline phases were identified in granite-based glass-ceramic materials at about $1000^{\circ} \mathrm{C}$ [43]. The appearance of the crystalline phases proved that the metakaolin-based geopolymer reinforced with basalt fibers exposed to temperatures over $1000{ }^{\circ} \mathrm{C}$ transformed into a ceramic material with higher strength and stiffness. As seen in Figure $8 \mathrm{c}$, there were crystalline phases and densification in the microstructure of the BGFs. Therefore, the heat treatment of BGFs at high temperatures created a denser crystalline structure, resulting in a considerable increase in their mechanical strengths (Figure 5). In general, the BGFs have the low thermal conductivity and excellent mechanical stability at high temperatures. As a result, they can be appropriate for fire protection applications.

\subsection{Fire Resistance of BGFs}

Fire resistance testing was conducted on the wood and steel plates coated by a BGF layer type S3 with different thicknesses using the flame of a gas burner. The samples of the wood boards and steel plates for fire resistance test were presented in Table 3. The temperature-time curves of the fire resistance test for the wood samples are presented in Figure 10. The fire-resistant times for the samples WS1, WS2, and WS3 were 22, 49, and $99 \mathrm{~min}$, respectively. The fire-resistant time increased with increasing the thickness of coated BGF layer. The fire-resistant time of the wood sample with $20 \mathrm{~mm}$ thickness of coated BGF layer was 4.5 times higher than that without coating the BGF layer. The temperatures on the fire-exposed surface of all samples increased rapidly during the initial period and then enhanced slowly beyond $15 \mathrm{~min}$. The temperatures on the unexposed surface of all samples raised gradually during the fire resistance testing. The non-fire surface temperatures of the wood 
samples did not exceed $200^{\circ} \mathrm{C}$, while the maximal temperature on their fire-exposed surface did not pass $800^{\circ} \mathrm{C}$.
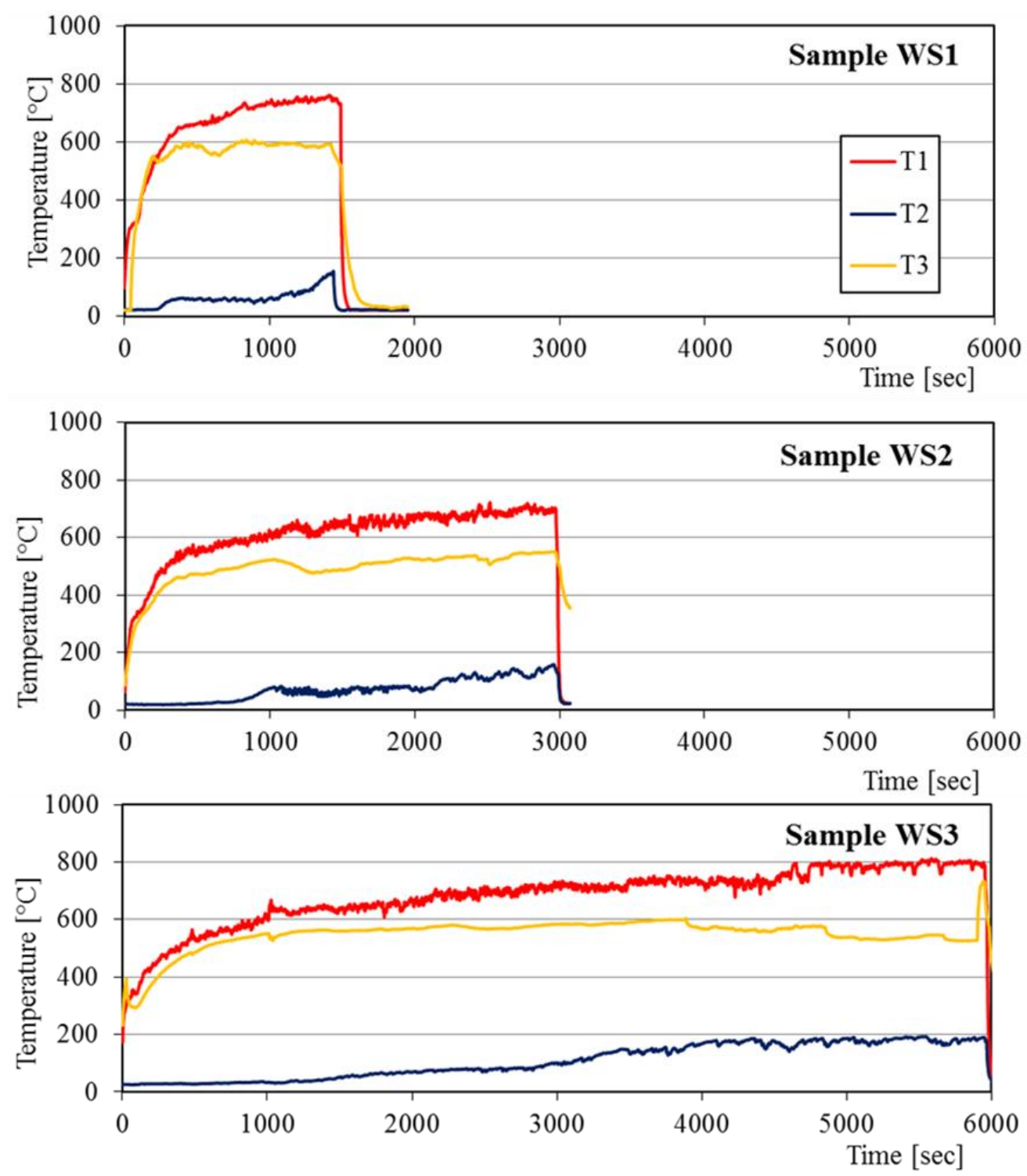

Figure 10. Temperature-time curves of fire resistance tests for the wood samples.

As with the wood boards, the fire resistance of the steel samples which was shown in Figure 11 depended on the thickness of the coated BGF layer. The fire-resistant time of the steel plates covered with the BGF layer was $41 \mathrm{~min}$ for the SS2 and $134 \mathrm{~min}$ for the SS3, but it was just 9 min for the SS1 (steel plate without coating) in the same testing condition. The fire-resistant time of the SS3 was about 15 times higher than that of the steel plate without coating the BGF (SS1). The maximal temperature on the fire-exposed surface of samples in the furnace did not exceed $900{ }^{\circ} \mathrm{C}$ and the unexposed surface temperatures did not surpass $300^{\circ} \mathrm{C}$. It is noted that the fire-resistant time of the wood and steel plates coated by a BGF layer depends not only on the coating thickness but also on the thermal conductivity of the substrate. With the same BGF coating thickness, the fire-resistant time of the steel sample (SS3) was 2.73 times higher than that of the wood sample (WS2). 

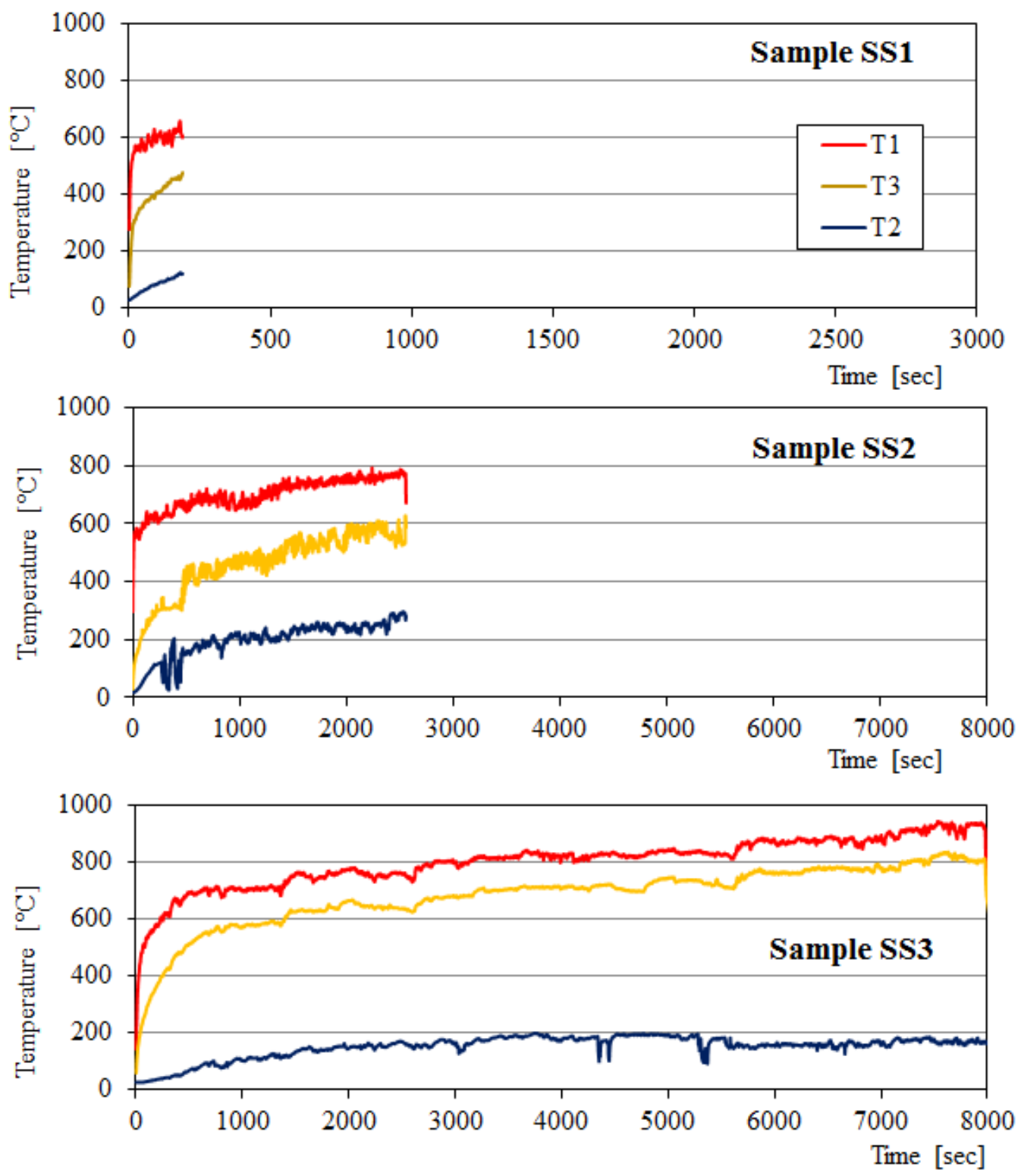

Figure 11. Temperature-time curves of fire resistance tests for the steel samples.

It is clear from Figure 12 that the surfaces of the wood and steel specimens coated by the BGF did not change significantly before and after fire resistance testing. The BGF retained its structure entirely without any significant macroscopic damage after fire resistance test, as reported by Sakkas et al. [26]. Macroscopic cracks did not appear on the exposed surfaces of the samples, but there was a change in the color of their surfaces after the fire resistance test. The slight color variation of the sample surfaces after the fire resistance testing is attributable to the fire-exposed surface temperature in the furnace lower than $900^{\circ} \mathrm{C}$. This temperature did not affect considerably the surface structure of the BGFs with high fiber content. As presented above, the BGFs exposed to high temperatures will become stronger. Therefore, the BGFs can be used as excellent coating materials for fire resistance applications. 

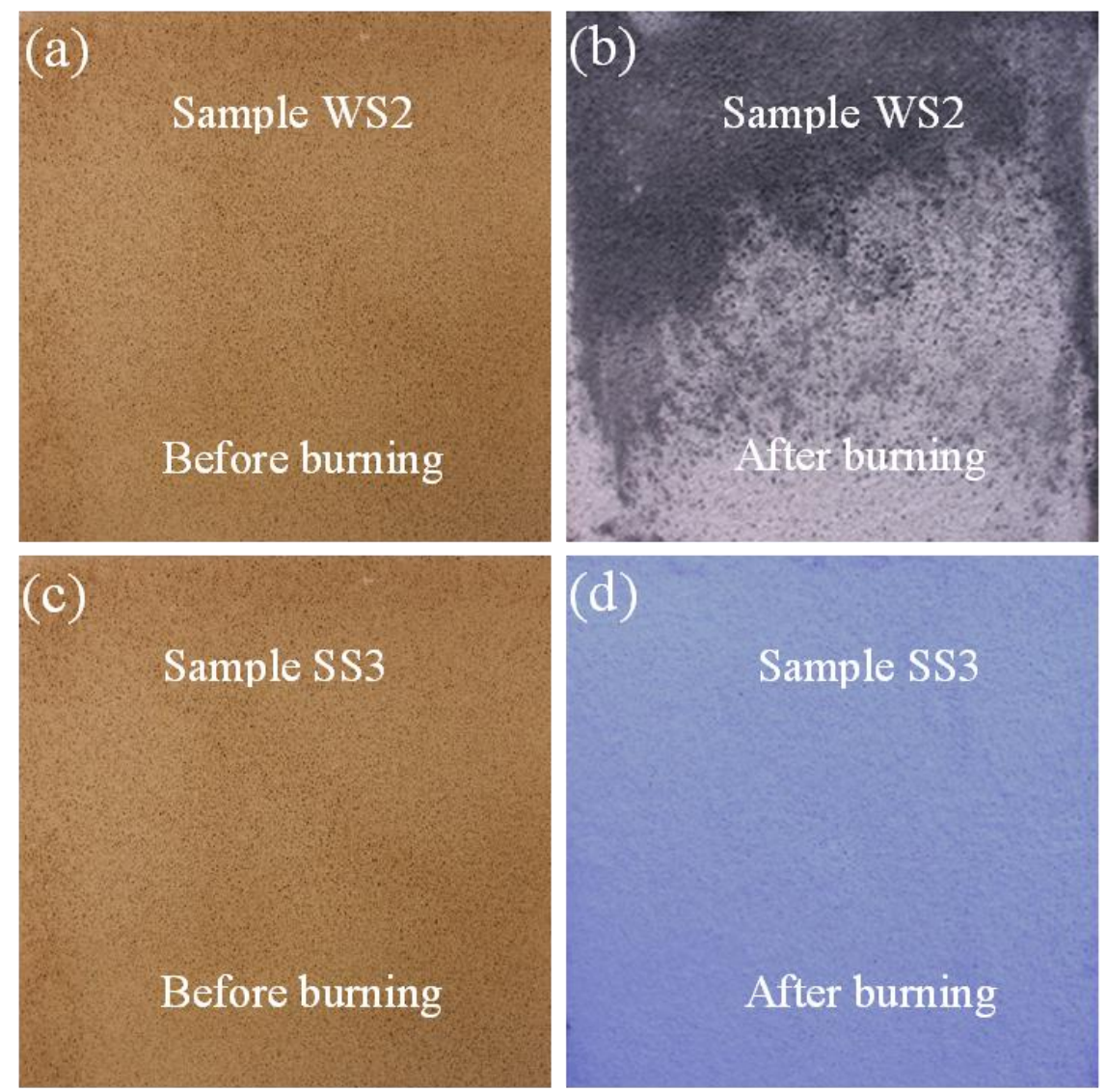

Figure 12. Photographs showing the fire-exposed surfaces of the samples WS2 and SS3: (a) and (c) before burning, (b) and (d) after burning.

\section{Conclusions}

The BGFs based on ground basalt fibers, aluminum foaming agent, and potassium-activated metakaolin-based geopolymer have been developed. Temperature-dependent properties of the BGFs, including apparent density, water absorption, mass loss, drying shrinkage, and compressive and flexural strengths, were measured and assessed. The following conclusions were pointed out:

- The apparent density and drying shrinkage of the BGFs increased with increasing the temperature from 400 to $1200{ }^{\circ} \mathrm{C}$. Under $600^{\circ} \mathrm{C}$ the mass loss was enhanced while the water absorption was reduced and they both changed slightly between 600 and $1000{ }^{\circ} \mathrm{C}$. Over $1000{ }^{\circ} \mathrm{C}$ the mass loss was decreased considerably, whereas the water absorption was enhanced. The compressive and flexural strengths of the high fiber loading BGFs were improved significantly at temperatures above $600{ }^{\circ} \mathrm{C}$ and reached the maximum at $1200^{\circ} \mathrm{C}$.

- The BGFs exposed to high temperatures exhibited a smooth change from amorphous to crystalline phase. Moreover, the BGFs with high fiber content exposed to high temperatures resulted in the dense crystalline structure, thereby improving their mechanical strengths. Therefore, the high fiber content BGFs showed excellent mechanical stability at high temperatures.

- The fire resistance of the wood and steel plates has been considerably improved after coating a BGF layer on their surface. The coated BGF kept its structural integrity without any substantial macroscopic fracture after fire resistance test. The longest fire-resistant times for the wood and steel boards were 99 and $134 \mathrm{~min}$, respectively.

In short, the BGFs with extraordinary fire resistance have great potential for fire protection applications. 
Author Contributions: Conceptualization, data curation, investigation, V.S.L.; Methodology, T.B.; Validation, P.D.N.; Formal analysis, K.E.B. and I.D.; Writing—original draft, V.S.L. and P.L.; Writing—review \& editing, V.S.L. and H.N.T. All authors have read and agreed to the published version of the manuscript.

Funding: This research received no external funding.

Acknowledgments: This work is financially supported by the Ministry of Education, Youth and Sports of the Czech Republic through the project "thermal Nano insulation for automotive, aviation and aeronautics" [Grant No.: TH04020189]. We would like to thank Pavlina Hajkova and Pavel Kejzlar for their help in XRD and SEM measurements.

Conflicts of Interest: The authors declare no conflict of interest.

\section{References}

1. Davidovits, J. Geopolymers and geopolymeric materials. J. Therm. Anal. 1989, 35, 429-441. [CrossRef]

2. Singh, B.; Ishwarya, G.; Gupta, M.; Bhattacharyya, S.K. Geopolymer concrete: A review of some recent developments. Constr. Build. Mater. 2015, 85, 78-90. [CrossRef]

3. Zhang, Z.; Provis, J.L.; Reid, A.; Wang, H. Geopolymer foam concrete: An emerging material for sustainable construction. Constr. Build. Mater. 2014, 56, 113-127. [CrossRef]

4. Bai, C.; Colombo, P. Processing, properties and applications of highly porous geopolymers: A review. Ceram. Int. 2018, 44, 16103-16118. [CrossRef]

5. Novais, R.M.; Pullar, R.C.; Labrincha, J.A. Geopolymer foams: An overview of recent advancements. Prog. Mater. Sci. 2020, 109, 100621. [CrossRef]

6. Le, A.S.; Hájková, P.; Kovacic, V.; Bakalova, T.; Lukáš, V.; Le, C.H.; Seifert, K.C.; Peres, A.P.; Louda, P. Thermal conductivity of reinforced geopolymer foams. Ceramics-Silikáty 2019, 63, 365-373. [CrossRef]

7. Ge, Y.; Cui, X.; Kong, Y.; Li, Z.; He, Y.; Zhou, Q. Porous geopolymeric spheres for removal of Cu (II) from aqueous solution: Synthesis and evaluation. J. Hazard. Mater. 2015, 283, 244-251. [CrossRef]

8. Ducman, V.; Korat, L. Characterization of geopolymer fly-ash based foams obtained with the addition of $\mathrm{Al}$ powder or $\mathrm{H}_{2} \mathrm{O}_{2}$ as foaming agents. Mater. Charact. 2016, 113, 207-213. [CrossRef]

9. Novais, R.M.; Ascensão, G.; Buruberri, L.H.; Senff, L.; Labrincha, J.A. Influence of blowing agent on the freshand hardened-state properties of lightweight geopolymers. Mater. Des. 2016, 108, 551-559. [CrossRef]

10. Bai, C.; Colombo, P. High-porosity geopolymer membrane supports by peroxide route with the addition of egg white as surfactant. Ceram. Int. 2017, 43, 2267-2273. [CrossRef]

11. Abdollahnejad, Z.; Pacheco-Torgal, F.; Félix, T.; Tahri, W.; Aguiar, J.B. Mix design, properties and cost analysis of fly ash-based geopolymer foam. Constr. Build. Mater. 2015, 80, 18-30. [CrossRef]

12. Chiu, Y.P.; Lu, Y.M.; Shiau, Y.C. Applying inorganic geopolymers added with aluminium powder to fire-resistant fillers. Mater. Res. Innov. 2015, 19, S5-S642. [CrossRef]

13. Sanjayan, J.G.; Nazari, A.; Chen, L.; Nguyen, G.H. Physical and mechanical properties of lightweight aerated geopolymer. Constr. Build. Mater. 2015, 79, 236-244. [CrossRef]

14. Hajimohammadi, A.; Ngo, T.; Mendis, P.; Sanjayan, J. Regulating the chemical foaming reaction to control the porosity of geopolymer foams. Mater. Des. 2017, 120, 255-265. [CrossRef]

15. Masi, G.; Rickard, W.D.; Bignozzi, M.C.; Van Riessen, A. The effect of organic and inorganic fibres on the mechanical and thermal properties of aluminate activated geopolymers. Compos. Part B Eng. 2015, 76, 218-228. [CrossRef]

16. Delair, S.; Prud'homme, É.; Peyratout, C.; Smith, A.; Michaud, P.; Eloy, L.; Joussein, E.; Rossignol, S. Durability of inorganic foam in solution: The role of alkali elements in the geopolymer network. Corros. Sci. 2012, 59, 213-221. [CrossRef]

17. Henon, J.; Alzina, A.; Absi, J.; Smith, D.S.; Rossignol, S. Potassium geopolymer foams made with silica fume pore forming agent for thermal insulation. J. Porous Mater. 2013, 20, 37-46. [CrossRef]

18. Böke, N.; Birch, G.D.; Nyale, S.M.; Petrik, L.F. New synthesis method for the production of coal fly ash-based foamed geopolymers. Constr. Build. Mater. 2015, 75, 189-199. [CrossRef]

19. Zhang, Z.; Provis, J.L.; Reid, A.; Wang, H. Mechanical, thermal insulation, thermal resistance and acoustic absorption properties of geopolymer foam concrete. Cem. Concr. Compos. 2015, 62, 97-105. [CrossRef] 
20. Feng, J.; Zhang, R.; Gong, L.; Li, Y.; Cao, W.; Cheng, X. Development of porous fly ash-based geopolymer with low thermal conductivity. Mater. Des. 2015, 65, 529-533. [CrossRef]

21. Papa, E.; Medri, V.; Kpogbemabou, D.; Morinière, V.; Laumonier, J.; Vaccari, A.; Rossignol, S. Porosity and insulating properties of silica-fume based foams. Energy Build. 2016, 131, 223-232. [CrossRef]

22. Minelli, M.; Medri, V.; Papa, E.; Miccio, F.; Landi, E.; Doghieri, F. Geopolymers as solid adsorbent for $\mathrm{CO}_{2}$ capture. Chem. Eng. Sci. 2016, 148, 267-274. [CrossRef]

23. Novais, R.M.; Buruberri, L.H.; Seabra, M.P.; Labrincha, J.A. Novel porous fly-ash containing geopolymer monoliths for lead adsorption from wastewaters. J. Hazard. Mater. 2016, 318, 631-640. [CrossRef] [PubMed]

24. Ge, Y.; Yuan, Y.; Wang, K.; He, Y.; Cui, X. Preparation of geopolymer-based inorganic membrane for removing $\mathrm{Ni}^{2+}$ from wastewater. J. Hazard. Mater. 2015, 299, 711-718. [CrossRef] [PubMed]

25. López, F.J.; Sugita, S.; Kobayashi, T. Cesium-adsorbent geopolymer foams based on silica from rice husk and metakaolin. Chem. Lett. 2014, 43, 128-130. [CrossRef]

26. Sakkas, K.; Panias, D.; Nomikos, P.; Sofianos, A. Potassium based geopolymer for passive fire protection of concrete tunnels linings. Tunn. Undergr. Space Technol. 2014, 43, 148-156. [CrossRef]

27. Sarker, P.K.; Mcbeath, S. Fire endurance of steel reinforced fly ash geopolymer concrete elements. Constr. Build. Mater. 2015, 90,91-98. [CrossRef]

28. Peng, X.; Li, H.; Shuai, Q.; Wang, L. Fire Resistance of Alkali Activated Geopolymer Foams Produced from Metakaolin and $\mathrm{Na}_{2} \mathrm{O}_{2}$. Materials 2020, 13, 535. [CrossRef]

29. Shuai, Q.; Xu, Z.; Yao, Z.; Chen, X.; Jiang, Z.; Peng, X.; An, R.; Li, Y.; Jiang, X.; Li, H. Fire resistance of phosphoric acid-based geopolymer foams fabricated from metakaolin and hydrogen peroxide. Mater. Lett. 2020, 263, 127228. [CrossRef]

30. Ye, J.; Zhang, W.; Shi, D. Effect of elevated temperature on the properties of geopolymer synthesized from calcined ore-dressing tailing of bauxite and ground-granulated blast furnace slag. Constr. Build. Mater. 2014, 69, 41-48. [CrossRef]

31. Chithambaram, S.J.; Kumar, S.; Prasad, M.M. Thermo-mechanical characteristics of geopolymer mortar. Constr. Build. Mater. 2019, 213, 100-108. [CrossRef]

32. Yang, Z.; Mocadlo, R.; Zhao, M.; Sisson, R.D., Jr.; Tao, M.; Liang, J. Preparation of a geopolymer from red mud slurry and class F fly ash and its behavior at elevated temperatures. Constr. Build. Mater. 2019, 221, 308-317. [CrossRef]

33. Kürklü, G. The effect of high temperature on the design of blast furnace slag and coarse fly ash-based geopolymer mortar. Compos. Part B Eng. 2016, 92, 9-18. [CrossRef]

34. František, Š.; Rostislav, Š.; Zdeněk, T.; Petr, S.; Vít, Š.; Zuzana, Z.C. Preparation and properties of fly ashbased geopolymer foams. Ceramics-Silikáty 2014, 58, 188-197.

35. Hlaváček, P.; Šmilauer, V.; Škvára, F.; Kopecký, L.; Šulc, R. Inorganic foams made from alkali-activated fly ash: Mechanical, chemical and physical properties. J. Eur. Ceram. Soc. 2015, 35, 703-709. [CrossRef]

36. Cilla, M.S.; de Mello Innocentini, M.D.; Morelli, M.R.; Colombo, P. Geopolymer foams obtained by the saponification/peroxide/gelcasting combined route using different soap foam precursors. J. Am. Ceram. Soc. 2017, 100, 3440-3450. [CrossRef]

37. Liu, L.P.; Cui, X.M.; Yan, H.; Liu, S.D.; Gong, S.Y. The phase evolution of phosphoric acid-based geopolymers at elevated temperatures. Mater. Lett. 2012, 66, 10-12. [CrossRef]

38. Liu, L.P.; Cui, X.M.; Qui, S.H.; Yu, J.L.; Zhang, L. Preparation of phosphoric acid-based porous geopolymers. Appl. Clay Sci. 2010, 50, 600-603.

39. Łach, M.; Mikuła, J.; Lin, W.; Bazan, P.; Figiela, B.; Korniejenko, K. Development and characterization of thermal insulation geopolymer foams based on fly ash. Proc. Eng. Technol. Innov. 2020, 16, 23-29. [CrossRef]

40. International Standards Organisation. Fire Resistance Tests, Elements of Building Construction (ISO 834); ISO: Geneva, Switzerland, 1980.

41. Tang, C.; Xu, F.X.; Li, G. Combustion performance and thermal stability of basalt fiber-reinforced polypropylene composites. Polymers 2019, 11, 1826. [CrossRef]

42. Mierzwiński, D.; Łach, M.; Hebda, M.; Walter, J.; Hebda, M.; Mikuła, J. Thermal phenomena of alkali-activated metakaolin studied with a negative temperature coefficient system. J. Therm. Anal. Calorim. 2019, 138, 4167-4175. [CrossRef] 
43. Bayrak, G.; Yilmaz, S. Granite based glass-ceramic materials. Acta Phys. Pol. A 2014, 125, 623-625. [CrossRef]

Publisher's Note: MDPI stays neutral with regard to jurisdictional claims in published maps and institutional affiliations.

(C) 2020 by the authors. Licensee MDPI, Basel, Switzerland. This article is an open access article distributed under the terms and conditions of the Creative Commons Attribution (CC BY) license (http://creativecommons.org/licenses/by/4.0/). 